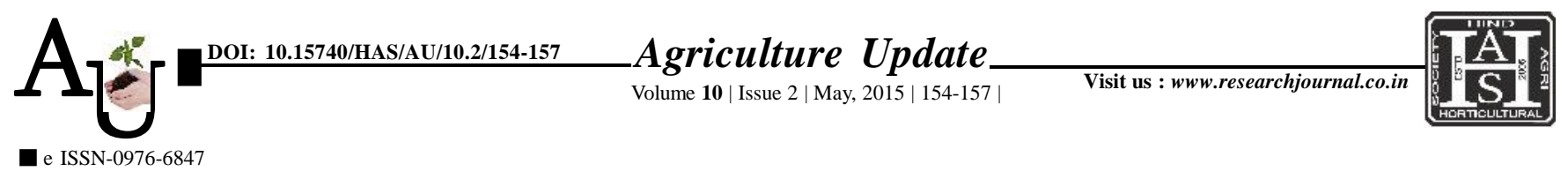

\title{
Rевевки автіст: : Effects of income on the communicational variable- A case of watershed development programme in Jabalpur district
}

\author{
SONAM AGRAWAL* AND NALINKHARE
}

Article Chronicle:

Received :

20.03.2015;

Revised :

02.04.2015;

Accepted :

15.04.2015

SUMMARY : The watershed development programme (WDP) initially envisaged as a measure for poverty alleviation and improved livelihoods has gained even greater importance. This study was conducted during year 2014- 15 in the Jabalpur district of M.P. The totals of 200 respondents were selected randomly for the study. Results showed that chi-square analysis of the selected four independent variables with dependent variable (i.e., income) indicated that, the variable extension participation, mass media exposure, contact with developmental agency, and cosmopliteness were positively significant at 0.05 per cent level of significance. The communicational profile analysis clearly indicated that majority of the beneficiaries had low extension participation, medium level of mass media exposure, low contact with development agencies and medium level of cosmopolitness.

How to cite this article : Agrawal, Sonam and NalinKhare (2015). Effects of income on the communicational variable- A case of watershed development programme in Jabalpur district. Agric. Update, 10(2): 154-157.

KEY WoRds :

Watershed,

Communicational

variable, Income

Author for correspondence :

SONAM AGRAWAL

Department of

Extension, Jawaharlal

Nehru Krishi Vishwa

Vidyalaya, JABALPUR

(M.P.) INDIA

See end of the article for

authors' affiliations 